\title{
無鉄心形超電導変圧器の特性解析
}

$\begin{array}{llllll}\text { 正 } & \text { 山 } & \text { 口 } & & \text { 浩 } & \text { (東工大) } \\ \text { 正 員 佐 } & \text { 藤 } & \text { 之 } & \text { 彦 } & \text { (東工大) } \\ \text { 正員片 } & \text { 岡 } & \text { 昭 } & \text { 雄 } & \text { (東工大) }\end{array}$

\section{Characteristics Analysis of Superconducting Power Transformer without Iron Core}

Hiroshi Yamaguchi, Member, Yukihiko Sato, Member, Teruo Kataoka, Member (Tokyo Institute of Technology)

With the advance of superconducting wires for a.c. power use, researches on superconducting power transformers are increasing. These transformers can be divided into two types; iron-core type ${ }^{(1)(2)}$ and air-core type ${ }^{(3) \sim(9)}$. The latter type has advantages such as absence of iron losses and magnetic saturation, and it has more possibility of reduction of size and weight. But the air-core transformer has a large magnetizing current due to the absence of iron core. Thus, researches have been carried out on the possibility of using the air-core transformer as a transformer that can also serve as a shunt reactor in a power transmission system. However, the operating characteristics of the air-core transformer, such as voltage regulation and reactance voltage, are not sure at present.

In this paper, the equivalent circuit without losses is first proposed. Since this equivalent circuit is expressed by means of the magnetic coupling factor and self-inductances of windings, the effect of these parameters on the transformer characteristics can be investigated with ease. Then, based on this equivalent circuit, the per-unit expressions for the air-core transformer characteristics are derived and the characteristics are analyzed in detail. The validity of the theoretical results are confirmed by experimental results obtained by the use of an experimental superconducting trans. former.

キーワード : 超電導変圧器, 無鉄心, 等価回路, 磁気結合係数

\section{1.まえがき}

交流用超電導線材の開発にともない, 变圧器に対し ても超電導化の検討が行われており，低損失化・小形 軽量化が期待されている。現在検討されている超電導 変圧器には, 鉄心形(1)(2) と無鉄心形(3)-(9) の 2 種類が あるが, 著者らの注目する無鉄心形超電導変圧器は, 鉄心形超電導変圧器に比べて, 小形軽量化が一段と進 屡する可能性がある。また，高調波発生などの鉄心に 起因する非線形現象もなく，無鉄損化によるいっそう の低損失化の可能性もある。

無鉄心形超電導変圧器は, 励磁電流が大きいので,
ケープル送電系統に扔ける充電電流を補償する分路り アクトルをかねた変圧器としての実現が考えられてお $り$, 概念設計 ${ }^{(4)(5)}$ や単巻変圧器の試作(6) などが報告さ れている。しかし, 変圧器の特性を特徵づける電圧変 動率やリアクタンス電圧, 分路リアクトルとして機能 する変圧器励磁容量と定格容量の関係などに関する一 般的検討は行われておらず，特性に関して不明確な点 が多い。こうした観点から，本論文では，無鉄心形超 電導変圧器の定常入出力特性を明らかにすることを目 的とする。

定常運転時における無鉄心形超電導変圧器の損失 は，ヒステリシス損失, 結合損失, 渦電流損失などの 
交流損失が主であり, 極めて小さい。従って, 変圧器 本体の定常入出力特性は，損失や効率の特性を除け ば，損失を無視して扱ってもさしつかえないと考えら れる。

そこで本論文では，損失や効率以外の定常入出力特 性の把握を第一に考え，まず損失を無視した等価回路 を提案する。この等価回路は, 巻線の磁気結合係数と 自己インダクタンスのニつの独立量に着目した等価回 路であり,これらの值が変圧器の特性に与える影響を 考察するのに便利な等価回路である。そして,この等 価回路を基に, 変圧器の特性式を単位法により一般化 した形で尊出し，これを用いて，規格化リアクタンス と磁気結合係数が変圧器の負荷特性に与える影響を明 らかにする。また, リアクタンス電圧, 無負荷励磁容 量, 一次定格值などと, 磁気結合係数および規格化り アクタンスの関係を示し，考察を行う。更に，試作変 圧器を用いた実験により，これらの検討結果の有効性 を確認する。

\section{2. 等価回路と理論特性の導出}

〈2・1〉等価回路の導出 損失を無視した変圧器 は図 1 で表される。ここで， $\dot{V}_{1}, \dot{I}_{1} ; \dot{V}_{2}, \dot{I}_{2}$ はそれぞ れ一次および二次の電圧, 電流 (フェーザ) である。 また, (a)図の $L_{1}, L_{2}$ は一次巻線, 二次巻線の自己 インダクタンス, $M$ は両巻線間の相互インダクタン スであり，(b)図の $L_{a}, L_{b}$ は直列巻線, 分路巻線の 自己インダクタンス, $M_{a b}$ は両巻線間の相互インダク タンスである。

(a) 図より, 2 巻線変圧器の電圧・電流の関係は次 式で与えられる。

$$
\left[\begin{array}{l}
\dot{V}_{1} \\
\dot{V}_{2}
\end{array}\right]=j \omega\left[\begin{array}{ll}
L_{1} & M \\
M & L_{2}
\end{array}\right]\left[\begin{array}{l}
\dot{I}_{1} \\
\dot{I}_{2}
\end{array}\right]
$$

単巻変圧器の場合も, $L_{1}=L_{a}+L_{b}+2 M_{a b}, L_{2}=L_{b}$,

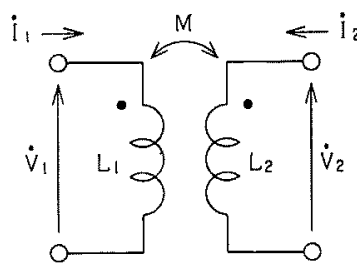

(a) 二䆖繶変王器

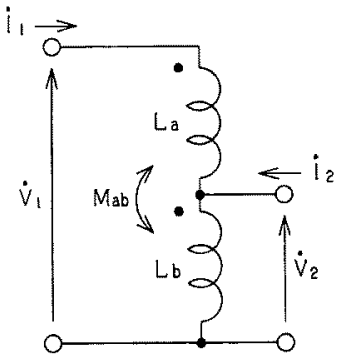

(b) 単巻变理器
図 1 変圧器の解析モデル

Fig. 1. Model of power transformer.
$M=L_{b}+M_{a b}$ とおけば(1)式を满足するので, 以下 では(1)式より T 形等価回路を導出する。

ここで, 二次側の量を一次側へ換算する換算係数 $a$ を次式で定義する。

$$
a^{2}=L_{1} / L_{2}
$$

この換算係数 $a$ は, ソレノイド形巻線の場合, 巻 線断面積 $S$, 長岡係数 $\mathscr{L}$, 高さ $h$, 巻数 $N$ を用いて 次式のように表される。ただし，添え字 1，2 はそれ ぞれ一次巻線惢よび二次巻線の量であることを示す。

$$
a^{2}=\frac{S_{1} \mathscr{L}_{1} / h_{1}}{S_{2} \mathscr{L}_{2} / h_{2}} \frac{N_{1}^{2}}{N_{2}^{2}}
$$

上式に示されるように, 本論文で用いる換算係数 $a$ は巻線の巻数だけでなく，その形状をも考虑した係数 である。

次に, $a$ を用いて, 二次側の量を次のように換算す る。ただし，の付いた文字は一次側への換算值を 示す。

$$
\begin{aligned}
& \dot{V}_{2}^{\prime}=a \dot{V}_{2} \\
& \dot{I}_{2}^{\prime}=\dot{I}_{2} / a
\end{aligned}
$$

以上より，(1)式は基準巻線の自己インダクタンス $L\left(=L_{1}\right)$ と磁気結合係数 $K\left(=M / \sqrt{L_{1} L_{2}}\right)$ の独立した 2 変数を用いて次のように整理される。

$$
\left[\begin{array}{c}
\dot{V}_{1} \\
\dot{V}_{2}^{\prime}
\end{array}\right]=j \omega\left[\begin{array}{cc}
L & K L \\
K L & L
\end{array}\right]\left[\begin{array}{c}
\dot{I}_{1} \\
\dot{I}_{2}^{\prime}
\end{array}\right]
$$

(5)式より，図 2 の等価回路が得られる。ただし， $\dot{Z}_{L}^{\prime}\left(=a^{2} \dot{Z}_{L}\right)$ は一次側に換算された負荷のインピーダ ンスである。また，負荷特性を考えるのに都合が良い ように, 図 2 の $\dot{I}_{2}^{\prime}$ の向きは(5)式の $\dot{I}_{2}^{\prime}$ とは逆向き にとってある。

一般に, 換算係数 $a$ の選び方は (2)式以外にも可 能であり, 図 2 以外にも通常の変圧器に用いられる等 価回路を含めて，種々の等価回路が存在する。しか し, 無鉄心形変圧器は, 一次・二次間の磁気結合が悪 く, 励磁電流も大きいなどの点で, 通常の変圧器と異 なる。従って，一次・二次間の磁気結合の程度を表す $K$ と，励磁電流の大きさを支配する $L$ との独立した

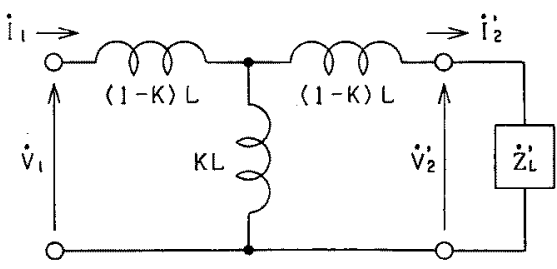

図 2 提案する T 形等価回路 Fig. 2. Proposed equivalent circuit. 
2 変数により変圧器特性を記述するのが便利であると 考えられる。そこで本論文では，(2)式の喚算係数を 用いた図 2 の等価回路を無鉄心形変圧器の等価回路と して提案し，以下，この回路に基づいて解析を進め る。

〈2・2〉 理論特性式の尊出 図 2 の等価回路の電 流・電圧の関係を定格二次電圧 $V_{2 r}^{\prime}$ と定格二次電流 $I_{2 r}^{\prime}$ を基準值として単位法で表すと, 次式が得られる。た だし，以下では添え字「 $n 」 は$ 単位法表記の量を, $\left\lceil r 」 は\right.$ は定格量を示す。また, $I_{2}^{\prime} / I_{2 r}^{\prime}=I_{2} / I_{2 r}, V_{2}^{\prime} / V_{2 r}^{\prime}=$ $V_{2} / V_{2 r}, Z_{L}^{\prime} /\left(V_{2 r}^{\prime} / I_{2 r}^{\prime}\right)=Z_{L} /\left(V_{2 r} / I_{2 r}\right)$ であるので, 一 次換算值を表す'は，以下では特に付けない。

$$
\left[\begin{array}{c}
\dot{I}_{1 n} \\
\dot{I}_{2 n} \\
\dot{V}_{2 n}
\end{array}\right]=\frac{\dot{V}_{1 n}}{\dot{D}_{n}}\left[\begin{array}{c}
j X_{n}+\dot{Z}_{2 n} \\
j K X_{n} \\
j K X_{n} \dot{Z}_{L n}
\end{array}\right]
$$

ただし， $X=\omega L$ であり， $\dot{D}_{n}$ は次式でちえられ。

$$
\dot{D}_{n}=j X_{n}\left\{\dot{Z}_{L n}+j\left(1-K^{2}\right) X_{n}\right\}
$$

変圧器の特性解析に際して, 一次側の定格電圧・電 流を定義しておく必要がある。通常の鉄心形変圧器で は，二次側の定格電流・定格電圧を与えれば，それら の一次換算值（ただし，このときの換算係数は巻数比 である）が一次定格值となる。しかし，無鉄心形変圧 器の場合, 分路リアクトルとしての機能を考慮した定 格の定義が必要であり，二次側の定格值を一次換算す る通常の定義では不十分である。よって, 本論文で は, 負荷力率角 $\varphi_{L}=\varphi_{L r}$ (定格力率角), $V_{2 n}=I_{2 n}=1$ pu となるとき（定格負荷状態）の一次電流を定格一 次電流 $I_{1 n r}$ と定義し, そのときの一次電圧を定格一 次電圧 $V_{1 n r}$ と定義する。この一次側の定格量はそれ ぞれ次式で定義される。

$$
\begin{aligned}
& V_{1 n r}=\left|\cos \varphi_{L r}+j\left\{\sin \varphi_{L r}+\left(1-K^{2}\right) X_{n}\right\}\right| / K \\
& I_{1 n r}=\left|\cos \varphi_{L r}+j\left(\sin \varphi_{L r}+X_{n}\right)\right| / K X_{n}
\end{aligned}
$$

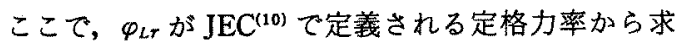
められる定数であること，(7)，(8)式で定義される 定格值が，それぞれ $1 \mathrm{pu}$ よ大きくなることに注意 が必要である。

（6)式より，無負荷特性は以下の式で表される。

$$
\begin{aligned}
& \dot{I}_{1 n 0}=\dot{V}_{1 n} / j X_{n} \\
& \dot{V}_{2 n 0}=K \dot{V}_{1 n} \ldots . .
\end{aligned}
$$

(10)式に示されるように, 無負荷電圧比 $V_{1 n} / V_{2 n 0}$ （変圧比）は $K$ に反比例する。また， $(7) ，(9)$ 式よ り, 定格一次電圧を印加したときの無負荷励磁容量 $Q_{n 0}$ は，次式で与えられる。

$$
Q_{n 0}=\frac{1+2\left(1-K^{2}\right) X_{n} \sin \varphi_{L r}+\left(1-K^{2}\right)^{2} X_{n}^{2}}{K^{2} X_{n}}
$$

この $Q_{n 0}$ 虫, 無鉄心形変圧器の一次側からみた分路 リアクトルとしての容量と考えることができる。

二次側短絡時には, (6)式より以下の式が得ら れる。

$$
\begin{aligned}
& \dot{I}_{1 n s}=\dot{V}_{1 n} /\left\{j\left(1-K^{2}\right) X_{n}\right\} \\
& \dot{I}_{2 n s}=K \dot{I}_{1 n s} \quad \cdots \ldots \ldots \ldots \ldots . . . . . .
\end{aligned}
$$

上式において $I_{2 n s}=1 \mathrm{pu}$ となるときの一次電圧の大 きさ，定格一次電圧との比加りアクタンス電圧 $q$ を次のように定義する。

$$
q=\left(1-K^{2}\right) X_{n} /\left(K V_{1 n r}\right)
$$

一般の鉄心形変圧器の場合, インピーダンス電圧 （抵抗分が無視できる場合はリアクタンス電圧）は， 二次短絡時の一次電流が定格值に等しくなるときの一 次電圧として決定され，このときの短絡二次電流も定 格值に等しくなると考えられる。しかし，無鉄心形変 圧器では, 淤磁電流や漏れ磁束の影響が大きいため, 短絡二次電流が定格值に一致するときの一次電流は (13)式より $I_{1 n}=1 / K$ となり，（8)式で定義される定 格一次電流より小さい。従って, 短絡一次電流が定格 值に一致するときの二次電流は, 定格值を超えてしま うことになる。このことから本論文では, 前述のよう に, 短絡二次電流が定格値に等しくなるときの一次電 圧からリアクタンス電圧を定義する。

なお， $q$ を上述のように定義すると，次に述べる電 圧変動率を考える上で都合が良い。また $q$ の逆数は, （7），(12），(13)式より，定格一次電圧を印加したと きの短絡二次電流に一致する。

（7），(10)，(14)式上り, 電圧変動率 $\varepsilon$ 㛎, 負荷 力率角を $\varphi_{L}$ とすると, 次式で表される。

$$
\begin{aligned}
\varepsilon & =K V_{1 n \tau}-1 \\
& =\frac{1}{\sqrt{1-q^{2} \cos ^{2} \varphi_{L}}-q \sin \varphi_{L}}-1
\end{aligned}
$$

このように, 無鉄心形超電導変圧器の場合, $\varepsilon$ 式 は, 通常の変圧器に対して用いられる式よりも複雑な 式になる。これも，励磁電流や漏れ磁束の影響が無視 できないことによる。しかし， $q$ が十分小さい範囲で は，(15)式を次式で近似することができる。

$$
\varepsilon=q \sin \varphi_{L}+\frac{1}{2} q^{2} \cos ^{2} \varphi_{L}
$$

この式は, 通常の変圧器に用いられる $\varepsilon$ 式におい て抵抗電圧を無視した式と同じ形である。

以上，本章では巻線のインダクタンスと磁気結合係 数に着目した等価回路を基に，単位法を用いて特性解 
析の基碳となる電纴・電流の関係式を導出した。そし て，この関係式から一次定格值を定義するとともに， 変圧器の特性が規格化リアクタンス $X_{n}$ と磁気結合係 数 $K$ で記述されることを明らかにした。これらの結 果より，哭鉄心形変圧器においては， $K, X_{n}$ を特性解 析や設計における基本的なパラメータとして考えるこ とがでる。

\section{3. 磁気結合係数と規格化リアクタンスの影響}

前章に示したように，規格化リアクタンス $X_{n}$ と磁 気結合係数 $K$ は変圧器の諸特性を決める重要な量で

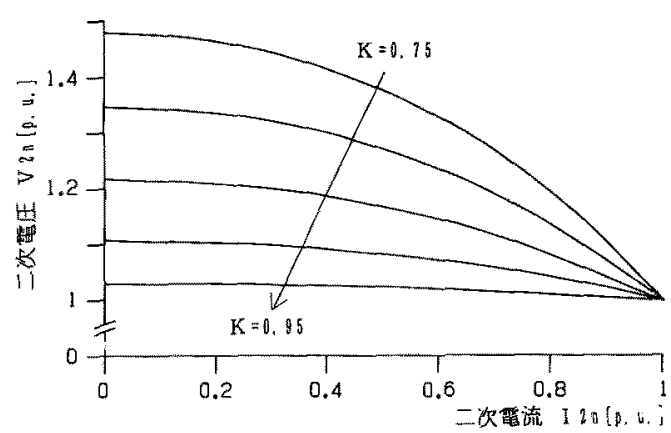

(a) 二次部E

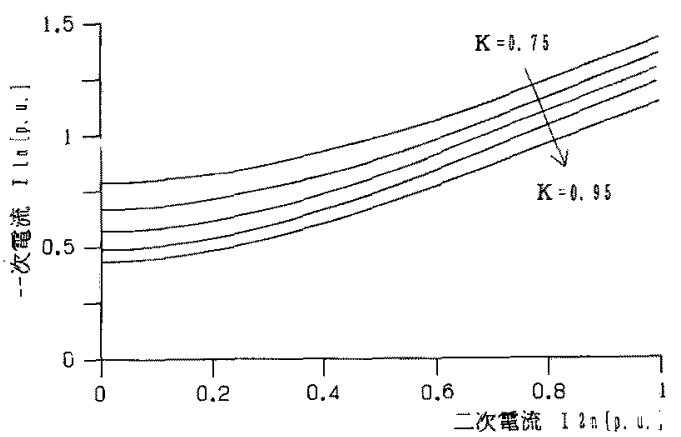

(b) 一次露流

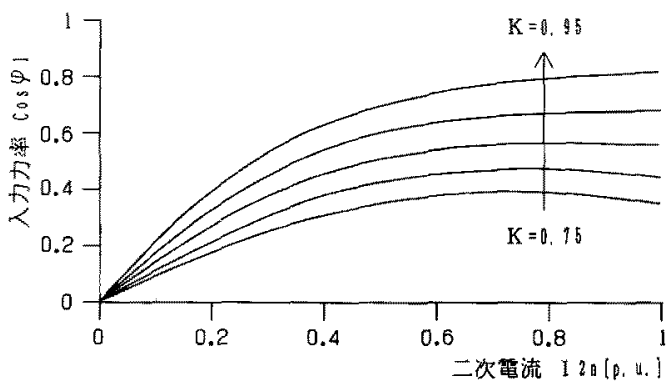

(c) 入力力新

図 3 磁気結合係数の影響 $\left(\varphi_{L}=\varphi_{L r}=0, X_{n}\right.$ $=2.5, K=0.95,0.9,0.85,0.8,0.75$ )

Fig. 3. Effect of $K$.
ある。そこで本章では、この 2 変数の負荷特性への影 響を考察する。なお，計算に際して，負荷は最も基本 的である純抵抗負荷とし, 定格出力点 $\left(V_{2 n}=I_{2 n}=1\right.$ pu）を通るように $V_{1 n}=V_{1 n r}$ とした。ただ， $V_{1 n r}$ の 計算に際しては $\varphi_{L r}=0$ とした。計算結果を図 3, 図 4 に示す。

〈3.1〉磁気結合係数の影響 図 3 は $X_{n}=2.5$ て $K$ を変化させた場合の負荷特性である。

(a)図の三次電圧特性において, $I_{2 n}=0$ のと道の $V_{2 n}$ の值は (10)，(15)式より $\varepsilon+1$ に一致するので, 各曲線の電圧変動率の值は，この関係から直ちに求め

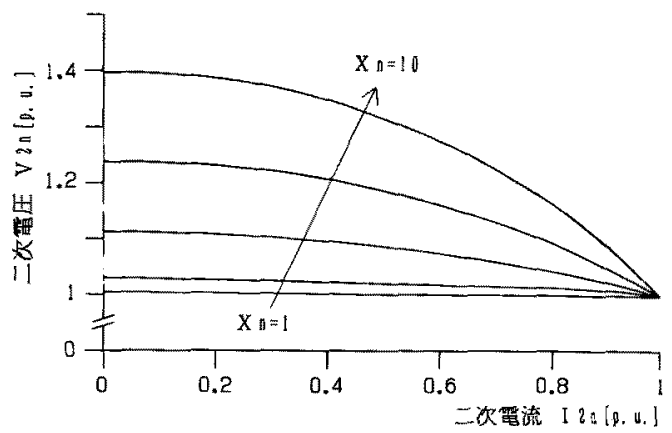

(a) 二次電圧

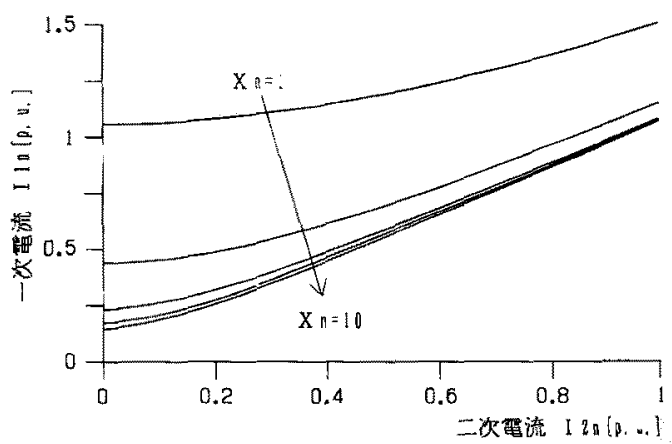

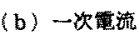

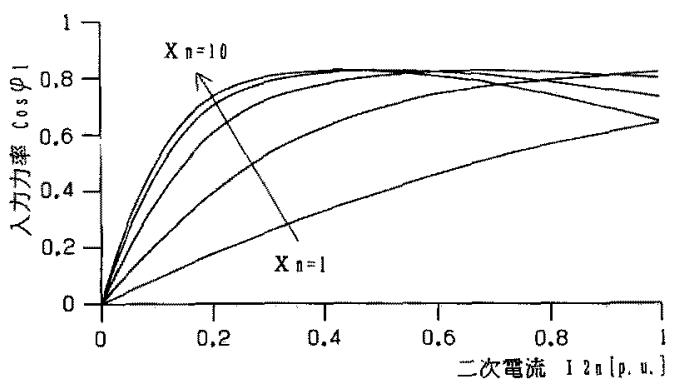

(c) 入力力

図 4 規格化りアクタンスの影響 $\left(\varphi_{L}=\varphi_{L r}\right.$ $=0, K=0.95, X_{n}=10,7.5,5,2.5,1$ )

Fig. 4. Effect of $X_{n}$. 
られる。図に示されるように，Kが大きいほど $\varepsilon ， す$ なわち $V_{2 n}$ の変動が小さいのは， $(7) ，(10)$ 式より 求められる無負荷二次電圧 $K V_{1 n r}$ が $K$ が大きいほど 小さいためである。このことは，(14)式のリアクタン 不電圧 $q$ が $K$ が大きいほど小さいことに対応する。 また，(b)図の一次電流は， $K$ が大きいほど小さい。 これは，(7)式の定格一次電圧 $V_{1 n r}$ が $K$ が大きいほ ど小さいためである。一方，(c)図の入力力率は $K$ が大きい活ど全体的に良く，最大值も大きい。一般 に, 入力力率の最大值とそのときの二次電流值は, 負 荷率角を $\varphi_{L}$ とすると，(6)式より以下の式で与えら れる。

$$
\begin{aligned}
& \left(\cos \varphi_{1}\right)_{\max }=\frac{K^{2} \cos \varphi_{L}}{2-K^{2}+2 \sqrt{1-K^{2}} \sin \varphi_{L}} \\
& I_{2 n}=\frac{K \ldots \ldots \ldots \ldots \cdots \cdots \cdots \cdots \cdots \cdots \cdots \cdots \cdots \cdots \cdots \cdots}{X_{n} \sqrt{\left(1-K^{2}\right)\left(2-K^{2}+2 \sin \varphi_{L}\right)}}
\end{aligned}
$$

(17)，(18)式より，入力力率の最大值は $K$ が大きい ほど大きく，そのときの二次電流も大きいことがわか る。また，入力力率の最大值が $K$ と $\varphi_{L}$ だけで決ま るという(17)式の性質は，興味深い性質といえる。

〈3・2〉規格化リアクタンスの影響 図 4 は $K=$ $0.95 て ゙ X_{n}$ を変化させた場合の負荷特性である。

(a) 図の二次電圧は， $X_{n}$ が小さいほど変動が小さ い。これは(7)式からわかるように，Xnが小さいほ ど無負荷二次電圧 $K V_{1 n r}$ が小さいためであり, 図 3 の場合と同様に, $X_{n}$ が小さいほど $q$ が小さいことに 対応している。また, 図 $4(\mathrm{~b})$ の一次電流と二次電流 の関係は， $X_{n}$ が大きいほど励磁電流の影響が小さく なるため比例関係に近づく。一方，(c)図の入力力率 は，(17)，(18)式に示されるように，力率が最大とな る二次電流值は $X_{n}$ が小さいほど大きいが, 最大值は $\varphi_{L}, K$ だけで決まるため一定である。

以上, 本章では, 磁気結合係数 $K$ と規格化リアク タンス $X_{n}$ が変圧器の負荷特性に与える影響を検討し た。その結果は，以下のようにまとめられる。

（1）一定の $X_{n}$ に対しては， $K$ が大きいほど電圧 変動や一次電流が小さく, 入力力率の特性も向上し, 全般的に特性が良くなる。

（2）一定の $K$ に対しては， $X_{n}$ が小さいほど，二 次電圧変動は小さい。しかし，一次電流（特に無負荷 一次電流）は $X_{n}$ が小さくなると大きく增加する。

以上の結果より, 無鉄心形超電導変圧器の設計に際 しては，Kと $X_{n}$ をどのように選ぶかが重要な問題と
なることがわかる。

\section{4. 変圧器巻線が具備すべき条件}

前章までの検討で, $X_{n}$ と $K$ が変圧器の特性に与え る影響が定性的に明らかになった。そこで，本章では $X_{n}$ と $K$ で決まる平面を用いて, リアクタンス電圧, 無負荷励磁容量, 一次側定格值などと, $X_{n}, K$ の関係 を示すとともに, 入出力仕様から変圧器巻線が具備す べき条件を決定する方法を明らかにする。図5 図 8 は，上記諸量を $X_{n}-K$ 平面に表示したものである。 図中の実線は $\varphi_{L r}=0$ として求めた計算值であり,。 印はこれまでの報告例 $\left(A^{(5)}, B^{(3)}, C^{(4)}\right.$ : 表 1), お よび次章で詳しく説明する試作変圧器 $(1,2,5,6,7$ : 表 4 ；ただし，定格二次電圧 $V_{2 \tau}=50 \mathrm{~V}$, 定格二次電流 $\left.I_{2 r}=50 \mathrm{~A}\right)$ の設計点を示している。なお， $A, B, C$ の設計点は，報告されている仕様を本論文で提案する 特性記述式に適用して求めた結果である。

図 5 は(14)式のq（リアクタンス電圧：右上りの曲 線群）を 0.05 ごとに，(11)式の $Q_{n 0}$ （無負荷励磁容 量：右下がりの曲線群）を 0.1 ごとに示したものであ る。図に示されるように，qは平面上を右下に向かう ほど増加し， $Q_{n 0}$ は平面上を左下に向かうほど増加す る。また， $q$ と $Q_{n 0}$ の值を指定することにより， $X_{n}$,

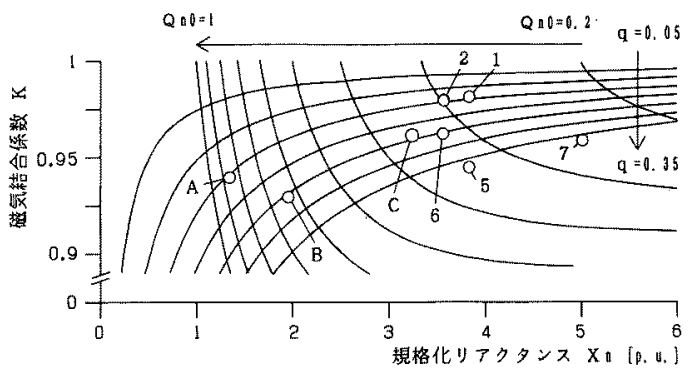

図 5 リアクタンス電圧と無負荷励磁容量

Fig. 5. $q$ and $Q_{n 0}$.

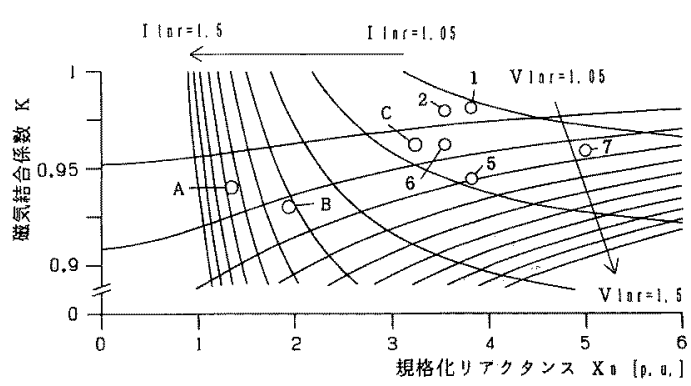

図 6 定格一次電圧拉よび定格一次電流 Fig. 6. $V_{1 n r}$ and $I_{1 n r}$. 


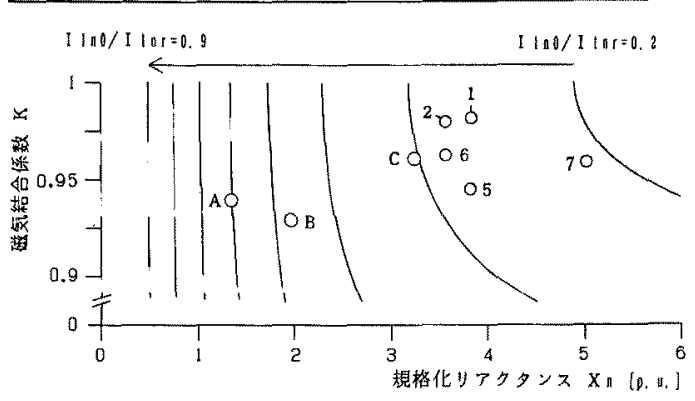

図 7 無負荷一次電流と定格一次電流の比

Fig. 7. Ratio of $I_{1 n 0}$ and $I_{1 n r}$.

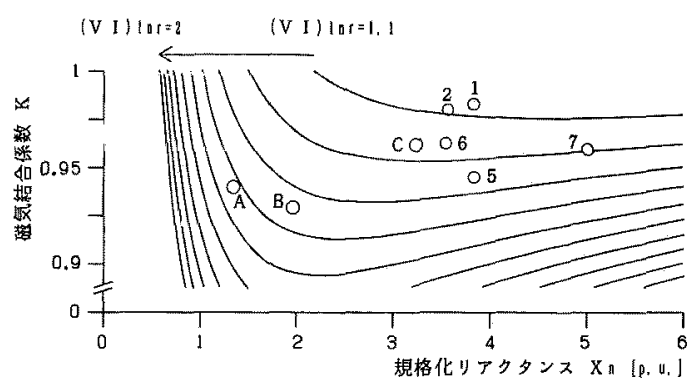

図 8 一次定格容量

Fig. 8. $(V I)_{1 n r}$.

表 1 これまでの報告例

Table 1. Examples of reported transformer.

\begin{tabular}{c|c|c|c|c|c}
\hline \multirow{2}{*}{ 結線 } & \multicolumn{2}{|c|}{ 定格電压 } & \multirow{2}{*}{ 出力容量 } & $K$ & $X_{n}$ \\
\cline { 2 - 3 } & - 次 & 二次 & & \\
\hline$A$ & $\frac{132}{\sqrt{3}} \mathrm{kV}$ & $\frac{66}{\sqrt{3}} \mathrm{kV}$ & $100 \mathrm{MVA}$ & 0.94 & 1.34 \\
\hline$B$ & $330 \mathrm{~V}$ & $150 \mathrm{~V}$ & $3 \mathrm{kVA}$ & 0.93 & 1.95 \\
\hline$C$ & $\frac{500}{\sqrt{3}} \mathrm{kV}$ & $\frac{66}{\sqrt{3}} \mathrm{kV}$ & $300 \mathrm{MVA}$ & 0.96 & 3.25 \\
\hline
\end{tabular}

$K$ の值が一意汇定まる。

$q$ の值としては, 比較的大容量の概念設計例である $A, C$ が $q=0.15 \sim 0.25$ の範囲にあることから，この 程度の範囲が比較的現実的と考えられる。 $B$ 极よび $1,2,6$ も小容量ではあるが， $q$ がほぽこの範囲内にあ る結線である。

図 6 は $(7) ，(8)$ 式により定義される一次定格の特 性を，それぞれ $0.05 こ ゙ と に$ 示したものである。定格 一次電圧 $V_{1 n r}$ (右上がりの曲線群) は平面上を右下 へ向かうに従い増加するが, 図 5 のqの値からみた 現実的結線 $(A, B, C, 1,2,6)$ では 1.05 1.1 pu 程 度である。一方, 定格一次電流 $I_{1 n r}$ (右下りの曲線群) は，平面上を左下へ向かうに従い大きくなる。この增 加は設計点により大きく異なり， $X_{n}$ が比較的大きな

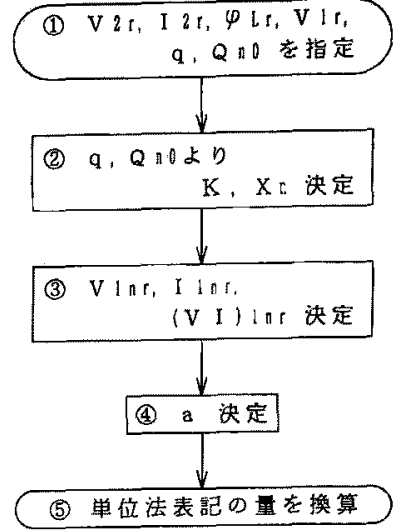

図 9 巻線諸星の決定

Fig. 9. Determination of winding values.

結線 1 では約 $1.05 \mathrm{pu}$ でるが， $X_{n}$ が小さい結線 $A$ では，分路リアクトルとしての機能が大きいため， 約 $1.33 \mathrm{pu}$ となる。

図 7 は定格一次電流 $I_{1 n r}$ に対する無負荷一次電流 (無負荷励磁電流) $I_{1 n 0}$ の比を示している。図に示さ れるように, 無負荷励磁電流の割合は $X_{n}$ が小さくな るに従い 1 に近づき, 結線 $A$ では定格の約 $60 \%$ (約 $0.8 \mathrm{pu})$ もの無負荷一次電流が流れる。

図 8 に示要一次定格容量 $(V I)_{1 n r}$, 寸なわち一次巻 線容量も, 図6の一次定格值の増加のため, 二次巻線 容量 (出力容量) に比べ大きくなり，ここで示した例 では, 一次巻線容量が二次巻線容量に比べ $0.1 \sim 0.4$ pu 程度增加する。従って, 一次巻線の設計に際して は，この容量増加の考慮が必要である。

図 5 〜図 8 を用いると, 変圧器巻線が具備すべき条 件を求めることができる。すなわち, 変圧器の入出力 仕様から $K, X_{n}$ の值を決定し, 巻線定格などを決め ることができる。この手順を図 9 に示す。

まず, 二次定格量 $V_{2 r}, I_{2 r}$ と定格負荷力率角 $\varphi_{L r}$, 定格一次電压 $V_{1 \mathrm{r}}$ を指定する。これらは, 変圧器て 接続しようとする系統の仕様から決まる量である。そ して，無負荷励磁容量（分路リアクトル容量） $Q_{n 0}$ 上 出力特性の指標であるリアクタンス電圧 $q$ の值を決 める(1)）。次に, 図 5 を用いて $q, Q_{n 0}$ の曲線を求め, その交点から $K, X_{n}$ の値を決定する(2)）。として， 図 6 を用いて一次定格 $V_{1 n r}, I_{1 n r}$ を求める。同様にし て, 図 7 加ら電流比 $I_{1 n 0} / I_{1 n r}$ か゚, 図 8 から一次巻線 容量 $(V I)_{1 n r}$ が求められる(3)。

次に，(3)式上り，換算係数 $a$ を次式で決定する (4) 0 


$$
a=V_{1 r} /\left(V_{2 r} V_{1 n r}\right)
$$

(19)式より，すべての単位法表記の量が実㻮の值に 換算され，定格一次電流や定格一次容量などの值が求 められる(5)。このとき，巻線の自己インダクタンス 挍よび相互インダクタンスは以下の式より求めら れる。

$$
\begin{aligned}
& \omega L_{1}=a^{2} X_{n}\left(V_{2 r} / I_{2 r}\right) \\
& \omega L_{2}=X_{n}\left(V_{2 r} / I_{2 r}\right) \cdots \\
& \omega M=a K X_{n}\left(V_{2 r} / I_{2 r}\right)
\end{aligned}
$$

以上の結果上り, (5)で求められた巻線定格と(20) ～(22)式より求められるインダクタンス值を満たす巻 線を設計すれば，所望の特性をもつ無鉄心形変圧器が 得られる。ただし，実際の変圧器の設計に抽いては， ここで求められた巻線定格やインダクタンス值を, 絶 緑や冷却の確保などをふまえたうえで実現する必要が 蓑り，別途，より詳細な検討が必要である。

以上，本章では， $X_{n}, K て ゙$ 表される平面を用いて， 試作変圧器を含むこれまでの報告例の一次巻線の定格 值や無負荷励磁電流の定格電流に対する割合などにつ いて，定量的に明らかにした。そして，リアクタンス 電压 $q$ と無急荷励磁容量 $Q_{n 0}$ 加 $X_{n}, K$ を求め, 巻 線が具備すべき条件を決定てきることを明らかにし た。これらの結果は, 無鉄心形変圧器の設計の指針と なると考えられる。

\section{5. 理論特性と実験結果の比較および考察}

以上示した解析の有効性を確認し，無鉄心形超電導 変珐器の特性を明らかにするため，本章では試作超電 導変圧器を用いて行った実負荷試験, 短絡試験の結果 を示す。なお，以下の測定の電源には，50 Hzの商用 電源を用いた。また，電圧の検出は，電流りード(銅) の抵抗の影篦を除くため,超電導線と常電導線の接続 部で行い，電流の検出は CTにより行った。

〈5・1〉 試作変圧器の仕様 試作変圧器の断面図 を图 $10 \mathrm{k}$, 使用している超電導線材の仕様を表 2 に, 羔線の仕様を表 3 に示す。

試作変圧器梳四つの独立した巻線をもち, 各巻線は 外側加巻線 1 , 巻線 2 , 巻線 3 , 巻線 4 の順に, 同 心状 4 重に配置されている。このため，巻線を適宜選 択して結線することにより，磁気結合係数 $K$ などの 值を変えた実験が可能である。また, 試作変圧器は細 長の構造になっているが, これは巻線で発生した磁束 が広がり、クライオスタットなどに鎖交することを極 力防ぐためである。巻線は，絶緑を施したより線を密 巻に巻き，層間にはFRP スペーサ $(0.5 \mathrm{~mm})$ を㨉入

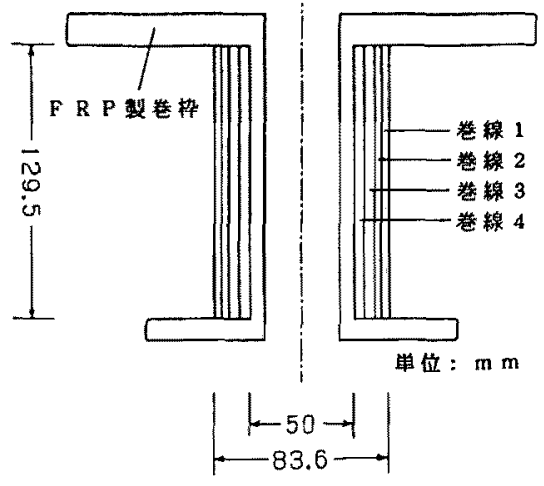

図 10 試作変圧器の断面

\begin{tabular}{|c|c|c|c|}
\hline \multicolumn{2}{|c|}{ 素線 } & \multicolumn{2}{|c|}{ より線 } \\
\hline マトリックス比 & & 䇣線本数 & 7本 \\
\hline $\mathrm{CuNi}: \mathrm{Cu}: \mathrm{Nb}^{\prime}$ & $2.2: 0.15: 1$ & 絶 粶 & 工ボキシ系策装 \\
\hline フィ タントト数 & 21,336 후 & 絶緑外佳 & $0.7 \mathrm{~mm}$ \\
\hline フィラメント径 & 的 $0.57 \mu \mathrm{m}$ & & \\
\hline 絶緑 & + & & \\
\hline
\end{tabular}

Fig. 10. Experimental power transformer.

表 2 超電導線の仕椂

Table 2. Specification of wire.

表 3 巻線の仕様

Table 3. Specification of windings.

\begin{tabular}{c|c|c|c|c}
\hline 䔲線 & 内径 $(\mathrm{mm})$ & 外径 $(\mathrm{mm})$ & 巻数 & インタタタタン $(\mathrm{mH})$ \\
\hline 1 & 78.6 & 81.6 & 584 & 12.18 \\
2 & 69.1 & 74.8 & 610 & 11.32 \\
3 & 60.1 & 68.1 & 811 & 15.99 \\
4 & 50.9 & 59.1 & 810 & 11.99 \\
\hline
\end{tabular}

*巻線の高さ住全卷繶とも $129.5 \mathrm{~mm}$ である。

し, 冷媒（液体へリウム）の通路と層間絶緑を確保し ている。

この試作変圧器の巻線の電流定格は, 定格電流の最 大值が直流臨界電流の半分になるように50 A とし， 電圧定格は定格電任印加時に巻線の最大経験磁束密度

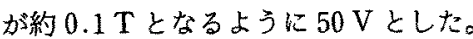

実験に用いた変圧器の結線は，一次巻線として 2 巻 線を直列結線したものを用い，二次巻線には 1 巻線だ けを用いた降圧結線の変圧器である。巻線の組合せと $K, X_{n}$ の值を表 4 に示す。なお, 試作変圧器の $K, X_{n}$ の值は，基準正弦波電源を用いて無負荷励磁試験を行 つた結果から求めた。表 4 に示すように，单巻結線 $(1,2,5,7)$ の磁気結合係数 $K$ は, $0.9815 \sim 0.9456$ と， どの結線でも大きな值が得られたが, 總緑 2 巻線結線 $(3,4,6,8)$ では, $0.9625 \sim 0.7401$ となり, 巻線の位置 関係により大きく異なる。 
表 4 試作変圧器の結線

Table 4. Connection of windings.

\begin{tabular}{|c|c|c|c|c|}
\hline 結線 & 一次巻線 & 二次巻線 & $K$ & $X_{n}$ \\
\hline 1 & \multirow{4}{*}{ 卷線 1+卷線 2} & 卷線 1 & 0.9815 & 3.826 \\
\hline 2 & & 巻線 2 & 0.9801 & 3.556 \\
\hline 3 & & 巻穆 3 & 0.8782 & 5.023 \\
\hline 4 & & 㲛線 4 & 0.7401 & 3.767 \\
\hline 5 & \multirow{4}{*}{ 巻線 $1+$ 巻線 3} & 巻線 1 & 0.9456 & 3.826 \\
\hline 6 & & 巻線 2 & 0.9625 & 3.556 \\
\hline 7 & & 巻線 3 & 0.9589 & 5.023 \\
\hline 8 & & 䒿線 4 & 0.8330 & 3.767 \\
\hline
\end{tabular}

*一次卷線の閶の゙+"位，巻線の直列接続を示す。

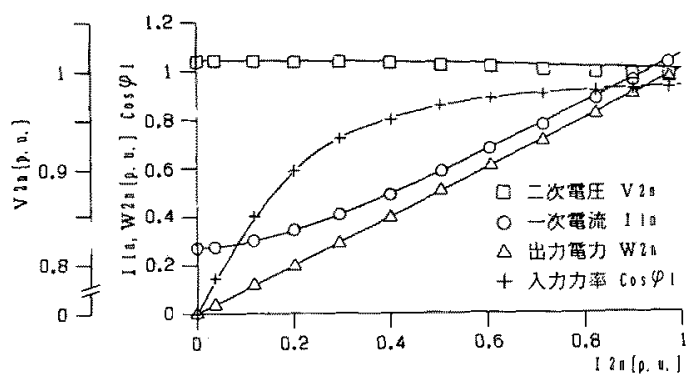

図 11 实負荷特性

Fig. 11. Load characteristics.

〈5-2〉実負荷試験 㘝11k，結線 10 純抵抗負 荷時の寒貴荷特性の例を示す。な极，実線流(6)式を 基に求めた理論値である。

この結線の場合，qが 0.1387 とさいため，二次 電压変動は小さい。また，励磁電流の影響により，一 次電流は二次電流に比例せす，入力力率名 1 より小 い。図11に扔いて，測定值と理論值はお扔むね一致 しており，理猃式の有效性が確認できるが，定格負荷 付近では，二次電压に若干のずれが見られる。これ は, 表 4 に示した等洒回路定数の湘定誤差や, 超電導 線と常電溥線の接続部にわずかに存在する接続抵抗の 影響と考えられる。この接続抵抗の影響が現れる原因 は、接続部の榡造上の制約から電圧検出線を接続部の 常電筫側から取り出さざるをえなかったためである。 なお，図11に示した以外の結線についての実験結果 からも，理猃式の有効性が確㒛された。

図 12 に実負荷試験の結果より得た電圧変動率を示 す。実線は(15)式より求めた理論値を，○印蝴定さ れた $\varepsilon$ (14)式から求めた $q$ を図示したものである。 数字は表 4 の結線番号である。㵋定值と理論値はほぼ 一致しているが，ばらつきが生じている。これは，図 110 場合と同様に，等価回路定数の湘定绫差や超電 導線と常電導線の接続抵抗の影墏と考えられる。

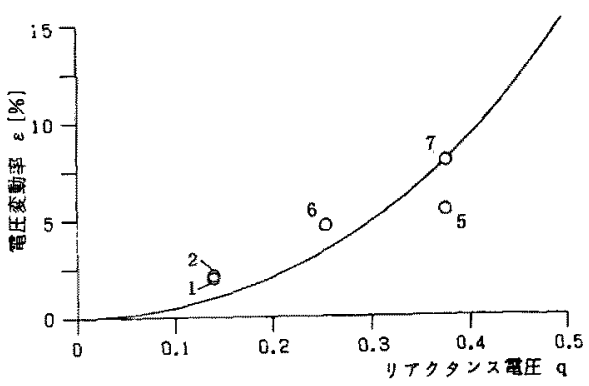

图 12 暼圧変陲率

Fig. 12. Voltage regulation.

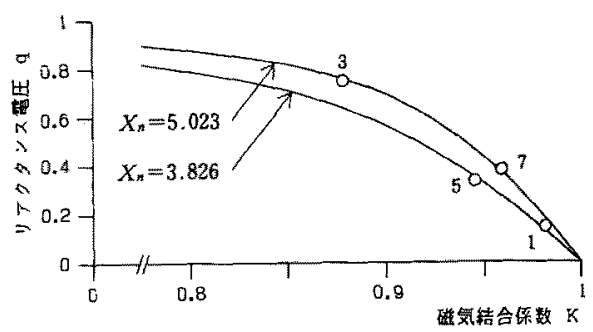

図 13 リアクタンス電生

Fig. 13. Reactance voltage.

〈5-3〉短絡語験 图 $13 に q の$ 測定例を示す。 四中の○印測定值であり，数字は表 4 の結線番号を 西している。また，実線は(14)式より求めた理論值て ある。このように, 理論値と测定值はよく一致し, （14）式の妥当性が確諰できる。なお，ここに示した以 外の結線についても同様の結果が得られた。

\section{6. まとめ}

以上，本論文では，損失特性や効率以外口定常入出 力特性の解明を目的とした無鉄心形超霋導変圧器の等 価回路を提案し，この等酎回路を用いた解析により， 一次定格と二次定格の関係を示すとともに，変圧器を 特徴づける量であるりアクタンス電压 $q$ や電压変動 率 $\varepsilon$, 份路リアクトルとしての容量と考えられる無負 荷励磁容量 $Q_{n 0}$ なとの理論式を示した。るして,こ れらが規格化りアクタンス $X_{n}$, 磁気結合係数 $K$ て記 述されることを明らかにした。また， $X_{n}, K$ が, 変压 器の特性に与える影墏について詳練に检討するととも に，入出力仕様から巻線が具備すべき条件を決める方 法を示した。これらは設計などの指針を与えるすので あると考えられる。更に, 試作超電導変㽵器を用いた 種々の実験により，これらの解析結果の有効性を確認 した。 
今回の考察では, 超電導変圧器の損失は十分小さい と考え, 損失を無視している。しかし, 実際の超電導 変圧器では損失が発生し, 付属冷凍機が不可欠であ る。従って, この冷涷機の冷却効率 $(1 / 500 \sim 1 / 1,000)$ を考えると, 変圧器の損失を把握することは非常に重 要である。損失も考慮した等価回路, 効率や損失の特 性については，おって報告を行う予定である。

また, 今回の考察では, 超電導変圧器が正常に動作 する範囲を取り扱い, 巻線のクエンチ現象については 対象外とした。従って, この点に関する検討も今後の 課題である。

最後に, 共同実験者で本学修士課程学生林 眞一 君, 森本 肇君, 学部学生 高田 徹君に謝意を表する。 (平成 4 年 10 月 23 日受付, 同 5 年 5 月 6 日再受付)

\section{文献}

(1) H. Riemersma, P. W. Eckels: "Application of Superconducting Technology to Power Transformers", IEEE Trans. Power Apparatus Syst., PAS-100, 3398 (1981)

（2）岸田・垣内・原口・守田・藤原・久保・中村・山田：「 $\mathrm{Nb}_{3} \mathrm{Sn}$ 超電導線を用いた実験用外鉄形超電導变圧器の製作J, 平 4 電気学会全大, 923

（3）石郷岡・岡田・上條・山本：「超電導空心単巻変圧器の試作 と試験」, 電気学会研資, SA-90-6 (平 2)

（4）秋田：「空心超電導変圧器の可能性について」, 同上, SA-90-7 (平 2)

（5）山本·石郷岡：「超電導変圧器の無鉄心化の可能性について」, 同上, SA-88-47 (昭 63)

（6）石郷岡・岡田・上條・山本: ‘超電導空心単巻変圧器の試作と その基本特性」, 電学論 B, 111, 448 (平 3-4)

（7）山口・佐藤・片岡：一無鉄心超電導変圧器の基本特性；同上 D, 111, 101 (平 3-1)

（8）片岡・山口・林・佐藤：「無鉄心形超電導変圧器の等価回路〕, 平 3 電気学会全大, 947

（9）山口・佐藤・林・片岡：「損失を考慮した無鉄心形超電導変圧 器の等価回路」, 電気学会研資, SA-91-62 (平 3)

（10）「JEC-204-1978：変圧器」, 電気学会電気規格調查会標染規格

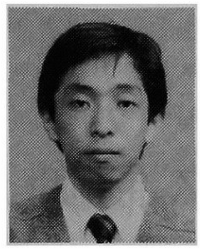

山口浩 (正員)

昭和 41 年 1 月 11 日生。平成元年 3 月 東京工業大学工学部電気・電子工学科卒 業。 3 年 3 月同大学大学院修士課程(電 気・電子工学専攻)修了。現在, 同博士後 期課程在学中。超電導応用に関する研究に従事。低温工学 会会員。

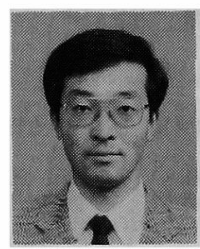

\section{佐 藤 之 彦 (正員)}

昭和 38 年 9 月 3 日生。 61 年 3 月東京 工業大学工学部電気・電子工学科卒業。 63 年 3 月同大学大学院修士課程 (電気 . 電子工学専攻)修了。現在, 同大学工学 部電気・電子工学科助手。この間, 半導体電力変換器の解 析と制御法, 超電導応用, 交流可変速制御などの研究に従 事。IEEE 会員。

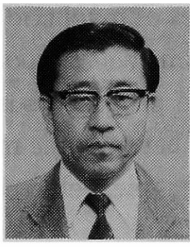

\section{片 岡 昭 雄 (正員)}

昭和 11 年 12 月 5 日生。 35 年 3 月東 京工業大学理工学部電気工学科卒業。 40 年 3 月同大学大学院博士課程(電気工学 専攻)修了。同年 4 月同大学理工学部電 気工学科助手, 42 年 11 月同助教授を経て, 現在, 同大学 工学部電気・電子工学科教授。電機変換工学講座担当。工 学博士。63 年度, 平成元年度電気学会編修理事。5 年度 より同学会本部代表評議員。昭和 54 年電気学会論文賞, 1982 年 IEEE-IAS 論文賞受賞。IEEE Fellow。 